\title{
ANALISIS KELAYAKAN USAHA BUDIDAYA UDANG VANAME POLA TRADISIONAL PLUS DI KECAMATAN SAMATURU KABUPATEN KOLAKA
}

\author{
Imelda Isamu ${ }^{1)}$, Idrus Salam ${ }^{2)}$, Lukman Yunus ${ }^{2)}$ \\ ${ }^{1)}$ Program Studi Magister Agribisnis Universitas Halu Oleo \\ Email: imelisamu@yahoo.co.id \\ ${ }^{2)}$ Dosen Tetap Fakultas Pertanian Universitas Halu Oleo, Kendari \\ Naskah diterima: 16 Januari 2018 \\ Naskah direvisi: 21 Februari 2018 \\ Disetujui diterbitkan: 30 Maret 2018
}

\begin{abstract}
Vaname shrimp is one of the aquaculture commodities which is the mainstay of export commodities of the government in improving non-oil and gas foreign exchange. This research aims to: (1) Analyze the income of shrimp farming business of Vanamee traditional pattern plus in Samaturu Sub-district of Kolaka Regency, and (2) Analyze the financial feasibility of shrimp farming business of Vanamee traditional pattern plus in Samaturu Sub-district of Kolaka. Respondents in this research are Vanamee shrimp farmers located in District Samaturu Kolaka District, with 34 farmers. The analysis used in this study is income analysis, $R / C$-ratio analysis, payback period $(P P)$ analysis and return of invesment (ROI) analysis. Result of research indicate that: (1) Vanamee shrimp farming income of traditional pattern plus in Samaturu Sub-district of Kolaka Regency is Rp 48,173.451 per hectare per year, and (2) Vanamee shrimp farming business in traditional pattern plus in Samaturu District Kolaka Regency is financially. Therefore, the role of government and private sector is needed to support the provision of cultivation facilities and infrastructure.
\end{abstract}

Keywords: income, Vanamee shrimp, farming, feasibility.

Intisari: Udang Vaname merupakan salah satu komoditas perikanan budidaya yang merupakan komoditi ekspor andalan pemerintah dalam memperoloeh devisa non migas. Penelitian ini bertujuan untuk: (1) Menganalisis pendapatan usaha budidaya udang Vanamee pola tradisional plus di Kecamatan Samaturu Kabupaten Kolaka, dan (2) Menganalisis kelayakan finansil usaha budidaya udang Vanamee pola tradisional plus di Kecamatan Samaturu Kabupaten Kolaka. Responden dalam penelitian ini pembudidaya udang Vanamee yang berada di Kecamatan Samaturu Kabupaten Kolaka, dengan 34 petani. Analisis yang digunakan dalam kajian ini analisis pendapatan, analisis R/C-ratio, analisis payback period (PP). Hasil penelitian menunjukkan bahwa: (1) Pendapatan usaha budidaya udang Vanamee pola tradisional plus di Kecamatan Samaturu Kabupaten Kolaka rata-rata sebesar Rp 48.173.451 perhektar pertahun, dan (2) Usaha budidaya udang Vanamee pola tradisional plus di Kecamatan Samaturu Kabupaten Kolaka layak secara finansial. Olehnya itu peran pemerintah dan swasta diperlukan dalam mendukungan penyediaan sarana dan prasarana budidaya.

Kata kunci: pendapatan, udang Vaname, budidaya, kelayakan.

\section{PENDAHULUAN}

Sulawesi Tenggara merupakan salah satu wilayah provinsi di Indonesia yang memiliki potensi pengembangan kelautan dan perikanan yang sangat menjanjikan. Data menunjukkan bahwa Propinsi Sulawesi Tenggara memiliki luas daratan 153.018,98 $\mathrm{KM}^{2}$ dengan panjang garis pantai sekitar 1.740 KM dengan luas perairan laut sekitar $114.879 \mathrm{KM}^{2}$. Terdapat 2 buah pulau besar (Pulau Buton dan 
Pulau Muna), 71 teluk, 540 buah pulau-pulau kecil (115 buah berpenghuni) serta beberapa buah selat dan tanjung yang dapat mendukung pengembangan usaha sector kelautan dan perikanan termasuk perikanan budidaya pertambakan.

Kabupaten Kolaka merupakan salah satu sentra utama pengembangan pertambakan di Provinsi Sulawesi Tenggara khusunya dalam memproduksi udang di tambak. Masyarakat di Kabupaten Kolaka baru beberapa tahun terakhir ini beralih jenis komoditas menjadi petambak udang vannamei, karena sebelumnya merupakan petambak dengan komoditasnya udang windu dan ikan bandeng. Peralihan jenis komoditi ini dikarenakan pada usaha pemdidayaan udang windu dan atau ikan bandeng, petambak sering mengalami kerugian akibat udang windu dan ikan bandeng selalu terserang virus yang ganas yang hingga kini belum terselesaikan, sehingga petambak tidak dapat memanen hasilnya, tidak dapat balik modal, bahkan mengalami kerugian besar. Hal tersebut mengakibatkan petambak masih menyimpan keteraumaan yang mendalam terhadap komoditi budidaya tambak udang windu.

Udang Vaname (Litopenaeus vannamei) merupakan salah satu komoditas perikanan budidaya yang secara umum diharapkn mampu menggeser posisi komodits udang windu (Penaeus monodon.sp) sebagai primadona ekspor, karena sistim usaha pembudidayaaanya tidak berbeda jauh dengan jenis udang windu atau lainnya. Pada dasarnya jenis udang-udangan merupakan komoditi ekspor andalan pemerintah dalam menggaet devisa non migas. Permintaan udang sangat besar baik pasar lokal maupun internasional, karena memiliki keunggulan nilai gizi yang sangat tinggi serta memiliki nilai ekonomis yang cukup tinggi menyebabkan pesatnya perkembangan budidaya udang vannamei saat ini, termasuk di Kabupaten Kolaka. Sulawesi Tenggara.

Kehadiran jenis udang Vaname ini diharapkan tidaknya hanya menambah pilihan bagi petambak tapi juga menopang kebangkitan usaha pertambakan terutama komoditas udang. Introduksi jenis udang baru yang lebih unggul dan tahan penyakit ini tampaknya menjadi salah satu kunci perwujudan mimpi di atas, selain memperkaya dan menambah alternafit jenis udang baru yang lebih tahan penyakit, peluang investasi terhadap pengembangan pertambakan udang diharapkan bakal kembali.

Berdasarkan hasil budidaya udang Vaname pada lahan uji coba di sejumlah daerah, menunjukkan tingginya produktivitas perolehan hasil, dibandingkan dengan jenis udang windu yang telah lama dikenal sebelumnya. Hadirnya jenis udang Vaname yang memiliki sejumlah keunggulan dan prospek keuntungan lebih baik, maka investasi tambak udang vannameisudah terlihat makin besar pada sejumlah sentra pertambakan di sejumlah daerah. Alasan para petani tambak untuk beralih ke udang vannamei karena udang vannamei termasuk dalam konsumsi rumah tangga memiliki sejumlah keunggulan antara lain lebih tahan terhadap penyakit, dapat di tebar dengan kepadatan tinggi, pertumbuhan lebih cepat, tahan terhadap lingkungan, dan waktu pemeliharaan yang lebih pendek yakni sekirar 70 - 100 hari per siklus.

Berdasarkan hal tersebut di atas, maka dipandang penting untuk melakukan penelitian mengenai seberapa besar tingkat kelayakan dan prospek usaha budidaya udang Vaname di salah satu kecamatan sentra produksi udang Vaname di Kabupaten Kolaka. Daerah yang dipilih adalah Kecamatan Samaturu dengan maksud dan tujuan untuk mengetahui seberapa besar tingkat kelayakanya dilihat aspek finansil dan prospek tidaknya untuk dijalankan masyarakat pertambakan tersebut secara berkelanjutan.

Adapun penelitian tentang kelayakan finansil dan prospeknya dilakukan untuk memberikan gambaran secara jelas tentang besarnya penggunaan modal atau investasi yang diperlukan dalam operasional usaha kegiatan produksi tambak terhadap tingkat penerimaan atau keuntungan yang diperoleh per musim tanam. Selain itu, dari hasil penelitian ini, petambak dan pelaku usaha perikanan lainnya dapat mengetahui besaran kisaran biaya yang digunakan dengan tingkat penerimaan atau keuntungan yang diperoleh dari usaha budidaya udang Vaname. Olehnya itu, tujuan utama dalam penelitian ini adalah untuk menganalisis pendapatan usaha budidaya udang Vaname pola tradisional plus di Kecamatan Samaturu Kabupaten Kolaka dan untuk menganalisis kelayakan finansil usaha budidaya udang Vaname pola tradisional plus di Kecamatan Samaturu Kabupaten Kolaka. 


\section{METODE PENELITIAN}

Penelitian ini dilaksanakan di Kecamatan Samaturu Kabupaten Kolaka Provinsi Sulawesi Tenggara. Pemilihan lokasi penelitian didasarkan atas prestasi produksi budidaya udang vaname pada tahun 2009-2016 di Provinsi Sulawesi Tenggara yang menempatkan Kabupaten Kolaka sebagai sentra produksi udang vaname terbesar. Berdasarkan jumlah populasi usaha budidaya udang vaname dengan pola tradisional plus di Kecamatan Samaturu Kabupaten Kolaka terdapat sebanyak 188 orang pembudidaya tambak. Olehnya itu jumlah sampel yang dipilih berdasarakan formulasi perhitungan pengambilan sample di atas adalah berjumlah 34 RTP, dimana formulasi pengambilan sampel dilakukan acak.Teknik analisis data yang digunakan dalam penelitian ini mengacu pada pendapat Soekartawi (1995), hasil penelitian Pratama, dkk (2012), serta Rifai, dkk (2014).

\section{Analisis pendapatan}

Analisis pendapatan bertujuan untuk menganalisis besarnya pendapatan yang diperoleh dari kegiatan usaha budidaya udang vaname pola tradisional plus yang dilakukan oleh petani. Pendapatan usaha dalam pengembangan budidaya udang vaname menggunakan persamaan sebagai berikut :

$\mathrm{I}=\mathrm{TR}-\mathrm{TC}$

Keterangan:

I $\quad=$ Income (pendapatan)

$\mathrm{TR}=$ Total revenue (penerimaan total)

$\mathrm{TC}=$ Total cost (biaya total)

\section{Analiss kelayakan usaha}

Analisis usaha digunakan untuk mengetahui kelayakan finansial usaha, yang terdiri atas analisis imbangan penerimaan dan biaya $(\mathrm{R} / \mathrm{C})$, analisis payback period $(\mathrm{PP})$ dan analisis return of invesment (ROI). Persamaan dari kriteria kinerja/kelayakan usaha tersebut adalah:

$\mathrm{R} / \mathrm{C}=\mathrm{TR} / \mathrm{TC}$

Keterangan:

Jika R/C > 1, usaha menguntungkan

Jika $\mathrm{R} / \mathrm{C}<1$, usaha rugi

Jika $\mathrm{R} / \mathrm{C}=1$, usaha kembali pokok

$\mathrm{PP} \quad=\mathrm{I} / \mathrm{B}$

ROI $=\mathrm{B} / \mathrm{I}$

Keterangan:

I = Biaya investasi

$\mathrm{B}=$ Benefit

\section{HASIL DAN PEMBAHASAN}

\section{Biaya Usaha Budidaya Udang Vaname}

Biaya merupakan sejumlah korbanan ekonomis yang secara nyata dibutuhkan untuk mendapatkan hasil atau produk dalam jumlah tertentu pada usaha budidaya udang vaname. Dalam penelitian ini komponen biaya dikelompokkan kedalam 2 (dua) jenis, yaitu biaya tidak tetap, dan biaya tetap.

\section{Biaya Tidak Tetap}

Biaya tidak tetap (variabel cost) biasanya didefinisikan sebagai biaya yang besar kecilnya dipengaruhi oleh jumlah produksi yang diperoleh atau biaya yang totalnya berubah-ubah dengan berubahnya jumlah produksi. Rata-rata biaya tidak tetap yang dikeluarkan oleh budidaya udang vaname dalam penelitian ini disajikan pada Tabel 1. 
Tabel 1. Rata-Rata Biaya Tidak Tetap Usaha Budidaya Udang Vaname Pola Tradisional Plus di Kecamatan Samaturu Kabupaten Kolaka, Tahun 2017

\begin{tabular}{clcrr}
\hline \multirow{2}{*}{ No } & \multirow{2}{*}{ Biaya Tidak Tetap } & \multicolumn{3}{c}{ Uraian $(\mathrm{Rp} / \mathrm{Ha} / \mathrm{Thn})$} \\
\cline { 3 - 5 } & Bibit/Benur & 14.100 .000 & \multicolumn{1}{c}{ Terendah } & \multicolumn{1}{c}{ Rata-Rata } \\
\hline 1 & Pakan & 51.840 .000 & 7.640 .000 & 9.942 .919 \\
2 & 4.320 .000 & 0 & 26.564 .565 \\
3 & Pupuk & 3.150 .000 & 0 & 1.315 .841 \\
4 & Kapur & 2.250 .000 & 0 & 779.765 \\
5 & Saponin & 3.937 .500 & 225.000 & 454.853 \\
6 & Bahan Bakar & 69.540 .000 & 18.294 .000 & 4.339 .462 \\
\hline \multicolumn{2}{c}{ Total } & & & 40.397 .405 \\
\hline
\end{tabular}

Sumber: Analisis Data Primer

Tabel 1 menunjukkan bahwa terdapat 6 (enam) kelompok besar pada jenis biaya tidak tetap yang digunakan petani dalam mengoperasikan usaha budidaya udang vaname per tahun, yakni biaya bibit/benur, biaya pakan, kapur, saponin dan biaya bahan bakar. Hasil penelitian menunjukkan bahwa besarnya biaya penggunaan bibit/benur pada usaha budidaya udang váname berkisar antara Rp 5.640.000 - Rp14.100.000/ha/thn, dengan biaya rata-rata sebesar Rp 9.942.919/ha/thn. Biaya penggunaan pakan pada usaha budidaya udang váname berkisar antara Rp 7.650.000 - Rp 51.840.000/ha/thn, dengan biaya rata-rata sebesar Rp 26.564.565/ha/thn. Biaya penggunaan pupuk pada usaha budidaya udang váname berkisar antara Rp 0 - Rp 4.320.000/ha/thn, dengan biaya rata-rata sebesar Rp 1.315.841/ha/thn.

Sementara itu, hasil penelitian juga menunjukkan bahwa biaya penggunaan kapur dan saponin pada usaha budidaya udang váname berkisar antara $\mathrm{Rp} 0$ - Rp 3.150.000/ha/thn dan Rp 0 - Rp 2.250.000/ha/thn, dengan biaya rata-rata masing-masing sebesar Rp 779.765/ha/thn dan Rp 454.853/ha/thn. Selanjutnya untuk penggunaan bahan bakar, biaya yang dikeluarkan petani udang vaname berkisar antara Rp 225.000 - Rp 3.937.500/ha/thn dengan biaya rata-rata sebesar Rp 1.339.462/ha/thn.

Selain itu, dari Tabel 1 diperoleh informasi bahwa rata-rata total biaya tidak tetap tertinggi berada pada biaya penggunaan pakan dan terendah berada pada biaya penggunaan saponin. Perbedaan nilai biaya tidak tetap pada masing-masing petani udang, dapat disebabkan karena perbedaan jumlah penggunaan input serta harga masing-masing input yang berbeda-beda.

\section{Biaya Tetap}

Biaya tetap (fixed cost) didefinisikan sebagai biaya yang relatif tetap jumlahnya, dan terus dikeluarkan walaupun produksi yang diperoleh banyak atau sedikit. Besarnya biaya tetap ini tidak tergantung pada besar kecilnya jumlah produksi yang diperoleh. Rata-rata biaya tetap yang dikeluarkan oleh budidaya udang vaname dalam penelitian ini disajikan pada Tabel 2.

Tabel 2. Rata-Rata Biaya Tetap Usaha Usaha Budidaya Udang Vaname Pola Tradisional Plus di Kecamatan Samaturu Kabupaten Kolaka, Tahun 2017

\begin{tabular}{clccc}
\hline \multirow{2}{*}{ No } & \multirow{2}{*}{ Biaya Tetap } & Tertinggi & Terendah & Rata-Rata \\
\cline { 2 - 4 } & Penyusutan & 3.475 .833 & 38.333 & 1.071 .049 \\
2 & Tenaga Kerja & 6.000 .000 & 3.000 .000 & 4.455 .882 \\
\hline & Total & 7.975 .833 & 3.180 .000 & 5.526 .931 \\
\hline
\end{tabular}

Sumber: Analisis Data Primer 
Tabel 2 menunjukkan bahwa terdapat 2 (dua) jenis biaya tetap yang dikeluarkan per tahun oleh pembudidaya udang vaname di Kecamatan Samaturu Kabupaten Kolaka, yakni biaya penyusutan, dan biaya tenaga kerja. Dalam penelitian ini diperoleh informasi bahwa biaya penyusutan terdiri atas biaya rumah jaga, pembuatan pintu pada pematang, biaya mesin pompa, timbangan, senter, dan biaya seser atau ancu.

Hasil penelitian menunjukkan bahwa biaya penyusutan pada usaha budidaya udang vaname di Kecamatan Samuturu bervariasi berkisar antara Rp 38.333 - Rp 3.475.833/ha/thn, dengan nilai rata-rata sebesar Rp 1.071.049/ha/thn. Nilai penyusutan ini diperoleh dengan menggunakan persamaan \{jumlah alat (nilai awal - nilai sisa)/umur ekonomis\}, yang selanjutnya dikonversikan dalam satu tahun. Dari persamaan tersebut, maka jelaslah bahwa tinggi rendahnya nilai penyusutan dipengaruhi oleh perbedaan jenis peralatan, jumlah peralatan, harga alat dan umur ekonomis dari masing-masing peralatan tersebut. Hal ini tentunya akan berdampak terhadap kemampuan fisik alat dalam bekerja, sehingga nilai ekonomis dari peralatan tersebut akan susut.

Tabel 2 juga menunjukkan bahwa selain biaya penyusutan, terdapat biaya tenaga kerja yang masuk sebagai komponen biaya tetap. Biaya tenaga kerja yang dimaksud adalah upaha pekerja pada saat mulai operasi usaha sampai kegiatan panen dilakukan, yang dibayarkan setiap kali siklus produksi. Hasil penelitian menunjukkan bahwa besarnya biaya tenaga kerja berkisar antara $\mathrm{Rp} 3.000 .000-\mathrm{Rp}$ 6.000.000/ha/thn, dengan rata-rata sebesar Rp 4.455.882/ha/thn. Selain itu, dari Tabel 2 diperoleh informasi bahwa rata-rata total biaya tetap tertinggi berada pada biaya penggunaan tenaga kerja dan terendah berada pada biaya penyusutan peralatan. Perbedaan nilai biaya tetap pada masing-masing petani udang vaname di Kecamatan Samaturu, juga dapat disebabkan karena perbedaan harga masingmasing input komponen biaya penyusutan serta adanya perbedaan siklus produksi pada masing-masing petani.

\section{Harga dan Jumlah Produksi}

Harga merupakan salah satu faktor yang dapat menentukan besarnya jumlah penerimaan dan pendapatan pada pembudidaya udang vaname. Besar kecilnya harga produksi tergantung dari kualitas dan ukuran ikan hasil panen. Dalam penelitian ini diperoleh informasi bahwa harga jual udang vaname di lokasi penelitian bervariasi berkisar antara Rp 40.000 - Rp 56.000/kg dengan rata-rata harga jual sebesar Rp 48.518/kg. Perbedaan harga produksi tersebut tentunya dapat disebabkan oleh ukuran dan kualitas dari hasil panen udang vaname dari masing-masing petani responden. Gambaran mengenai besarnya jumlah produksi budidaya udang vaname di Kabupaten Kolaka dapat dilihat pada Tabel 3.

Tabel 3. Rata-Rata Harga dan Produksi Usaha Usaha Budidaya Udang Vaname Pola Tradisional Plus di Kecamatan Samaturu Kabupaten Kolaka, Tahun 2017

\begin{tabular}{clrrr}
\hline No & \multicolumn{1}{c}{ Uraian } & Tertinggi & Terendah & Rata-Rata \\
\hline 1 & Harga Produksi $(\mathrm{Rp} / \mathrm{Kg})$ & 56.000 & 40.000 & 48.518 \\
2 & Jumlah Produksi $(\mathrm{Kg} / \mathrm{Ha} / \mathrm{Thn})$ & 1.100 & 400 & 660 \\
\hline
\end{tabular}

Sumber: Analisis Data Primer

Sementara itu, produksi yang dimaksud dalam penelitian ini adalah hasil akhir dari usaha budidaya udang vaname, yakni jumlah ikan udang vaname yang dinyatakan dalam satuan kilogram per tahun $(\mathrm{kg} / \mathrm{thn})$. Seperti halnya pada harga produksi, rata-rata jumlah produksi udang vaname dalam penelitian ini juga bervariasi berkisar antara $400-1.100 \mathrm{~kg} / \mathrm{ha} / \mathrm{thn}$, dengan rata-rata sebesar 660 $\mathrm{kg} / \mathrm{ha} / \mathrm{thn}$. Bervariasinya jumlah produksi ini selain disebabkan karena perbedaan jumlah siklus produksi, juga dapat disebabkan karena perbedaan jumlah biaya variabel (operasional) yang dikeluarkan oleh masing-masing responden. Semakin besar investasi dan kapasitas usaha, maka produksi atau hasil panen udang vaname akan semakin besarnya pula. 


\section{Pendapatan Budidaya Udang Vaname}

Pendapatan yang dimaksud dalam penelitian ini adalah rata-rata jumlah penerimaan dari usaha budidaya udang vaname setelah dikurangi dengan rata-rata seluruh biaya produksi dalam satu hektar per tahun. Sementara itu, penerimaan merupakan rata-rata harga produksi per tahun dikalikan dengan rata-rata jumlah produksi per hektar per tahun. Gambaran mengenai jumlah penerimaan dan pendapatan usaha budidaya udang vaname dapat dilihat dalam Tabel 4.

Tabel 4. Rata-Rata Penerimaan dan Pendapatan Usaha Budidaya Udang Vaname Pola Tradisional Plus di Kecamatan Samaturu Kabupaten Kolaka, Tahun 2017

\begin{tabular}{clrrc}
\hline No & $\begin{array}{c}\text { Uraian } \\
(\text { Rp/Ha/Thn })\end{array}$ & Tertinggi & Terendah & Rata-Rata \\
\hline 1 & Total Biaya & 76.195 .062 & 23.253 .186 & 45.924 .353 \\
2 & Penerimaan & 158.400 .000 & 59.340 .000 & 94.097 .804 \\
3 & Pendapatan & 90.964 .146 & 31.554 .152 & 48.173 .451 \\
\hline
\end{tabular}

Sumber: Analisis Data Primer

Tabel 4 menunjukkan bahwa aktivitas usaha budidaya udang vaname di Kabupaten Kolaka memperoleh pendapatan atau dengan kata lain memiliki keuntungan dari segi ekonomi. Gambaran tersebut dapat dilihat dari jumlah rata-rata penerimaan yang mampu menutupi seluruh rata-rata total biaya produksi pada usaha budidaya udang vaname. Besarnya jumlah pendapatan bervariasi berkisar antara Rp 31.554.152 - Rp 90.964.146/ha/thn, dengan rata-rata sebesar Rp 48.173.451/ha/thn. Bervariasinya jumlah pendapatan tersebut, selain disebabkan karena perbedaan kapasitas usahal, juga dapat disebabkan karena perbedaan jumlah investasi modal yang telah dikeluarkan oleh masing-masing petani responden.

\section{Kelayakan Usaha Budidaya Udang Vaname}

Kelayakan usaha budidaya udang vaname yang dimaksud dalam kajian ini adalah kelayaan finansial yang terdiri atas analisis imbangan penerimaan dan biaya (R/C-Ratio), analisis payback period (PP) dan analisis return of invesment (ROI). Komponen variabel yang digunakan untuk mengukur kinerja usaha meliputi biaya investasi, biaya produksi, penerimaan, usaha dan pendapatan yang diperoleh dari usaha perikanan (Febrianto, 2008 dalam Neliyana, dkk., 2014). Deskripsi mengenai kelayakan usaha budidaya udang vaname disajikan dalam Tabel 5.

Tabel 5. Kelayakan Usaha Budidaya Udang Vaname Pola Tradisional Plus di Kecamatan Samaturu Kabupaten Kolaka, Tahun 2017

\begin{tabular}{|c|c|c|c|c|}
\hline No & Uraian & Tertinggi & Terendah & Rata-Rata \\
\hline 1 & R/C-Ratio & 2,71 & 1,71 & 2,09 \\
\hline 2 & PP (Periode Poduksi) & 3,82 & 1,57 & 2,30 \\
\hline 3 & ROI (\%) & 171,17 & 71,29 & 108,62 \\
\hline
\end{tabular}

Sumber: Analisis Data Primer

Analisis R/C-ratio merupakan analisis pengimbangan antara penerimaan dan biaya. Analisis ini digunakan untuk melihat apakah biaya yang dikeluarkan menghasilkan cukup penerimaan untuk memperoleh keuntungan serta untuk menilai efisiensi biaya yang telah dikeluarkan. Tabel 17 menunjukkan bahwa usaha budidaya udang vaname di Kecamatan Samaturu Kabupaten Kolaka menguntungkan dan layak secara finansial. Hal ini dapat dilihat dari besarnya nilai R/C-ratio yang berkisar antara 1,70 - 2,71 dengan rata-rata $\mathrm{R} / \mathrm{C}$ ratio sebesar 2,09 atau lebih besar 1 . Hal ini memberikan makna bahwa setiap satu rupiah biaya yang dikeluarkan pada usaha budidaya udang vaname, akan menghasilkan penerimaan rata-rata sebesar $\mathrm{Rp} 2,09,-$. 
Payback period (PP) adalah suatu periode yang diperlukan untuk menutup kembali pengeluaran investasi dengan menggunakan aliran kas. Paybac period merupakan rasio antara pengeluaran investasi dengan keuntungannya dalam suatu waktu tertentu (Umar, 2003). Hasil penelitian menunjukkan bahwa tingkat pengembalian modal usaha budidaya udang vaname juga bervariasi, yakni berkisar antara 1,57 - 3,82 periode produksi dengan rata-rata tingkat pengembalian modal selama 2,30 periode produksi. Hal ini memberikan gambaran bahwa seluruh modal atau biaya investasi yang dikorbankan pada usaha budidaya udang vaname akan kembali pada saat periode produksi rata-rata 2,30 kali periode. Nilai tersebut relatif singkat, dimana dalam kajian ini diperoleh informasi bahwa periode produksi/panen usaha budidaya udang vaname berkisar antara 2 - 4 periode per tahun dengan rata-rata 3 periode per tahun. Kondisi tersebut juga mengindikasikan bahwa dari aspek tingkat pengembalian modal usaha, budidaya udang vaname layak untuk dikembangkan.

Selanjutnya, kelayakan usaha budidaya udang vaname yang ditinjau dari aspek return of invesment (ROI), juga menunjukkan bahwa kondisi usaha layak untuk dikembangkan. Hal ini dapat dilihat dari nilai ROI yang diperoleh yakni berkisar antara adalah 71,29\% - 171,17\% dengan rata-rata sebesar $108,62 \%$. Gambaran tersebut memberikan makna bahwa dengan rata-rata total biaya (investasi) sebesar Rp 45.924.353/ha/thn, akan mampu memberikan tingkat keuntungan rata-rata sebesar 108,62\%.

\section{KESIMPULAN DAN SARAN}

\section{Kesimpulan}

1. Pendapatan usaha budidaya udang vaname pola tradisional plus di Kecamatan Samaturu Kabupaten Kolaka rata-rata sebesar Rp 48.173.451 perhektar pertahun.

2. Usaha budidaya udang vaname pola tradisional plus di Kecamatan Samaturu Kabupaten Kolaka layak diusahakan secara finansial.

\section{Saran}

1. Bagi pembudidaya udang vaname, sebaiknya menambah daya kapasitas usaha dan perbaikan manajemen usaha, agar produksi dan pendapatan yang diperoleh lebih maksimal.

2. Bagi pemerintah dan pihak swasta, perlu adanya dukungan dalam penyediaan sarana dan prasarana, khususnya pembudiaya dengan kapasitas produksi rendah, guna mendukung pengembangan usaha budidaya udang vaname yang berkelanjutan di Kabupaten Kolaka.

\section{DAFTAR PUSTAKA}

Adiwilaga, A. 1982. Ilmu Usahatani. Alumni. Bandung.

Alwi, S. 1989. Alat-Alat Analisis dalam pembelanjaan (Edisi Revisi). Andi Offset. Yogyakarta.

Ariawan, K. dkk. 2005. Peningkatan produksi udang merguiensis melalui optimasi dan pengaturan oksigen. Laporan Tahunan. Balai Besar Pengembangan Budidaya Air Payau. Jepara

Austin, J.E. 1992. Agroindustrial Project Analysis. The John Hopkins University Press. Baltimore and London.

Bahari. dkk. 1998. Teknik Analisa Usaha Tani. Fakultas Pertanian Unhalu. Kendari.

Dahuri, R. 2002. Usaha Pertambakan Udang Vaname. Prospektif BPEN. Jakarta.

Dinas Kelautan dan Perikanan Provinsi Sulawesi Tenggara. 2015. Laporan Tahunan Statistik Perikanan Budidaya 2014. Kendari.

Djamin, Z. 1993. Perencanaan dan Analisa Proyek. LPFE - UI. Jakarta.

Doll, J.P. dan Orazem F. 1984. Production Economics. Second Edition. John Wiley and Sons.

Downey, W.D. dan Ericsson S.P. 1989. Manajemen Agribisnis. Edisi Kedua. Erlangga. Jakarta.

Endhay, K. 2003. Petunjuk Teknis Budidaya Rumput Laut. Direktorat Pembudidayaan Ikan. Direktorat Jenderal Perikanan Budidaya. Jakarta

Gittinger, J.P. 1986. Analisa Ekonomi Proyek-Proyek Pertanian. Universitas Indonesia Press. Jakarta. 
Gittinger, J.P. dan Adler, H. 1990. Evaluasi Proyek. Rineka Cipta. Jakarta.

Haliman dan Adijaya. 2004. Pembudidayaan dan Prospek Pasar Udang PutihyangTahan Penyakit. Penebar Swadaya. Jakarta

Hendrajat, A.E; M. Mangampa; H. Suryanto. 2007. Budidaya Udang Vaname Pola Tradisional Plus di Kabupaten Maros Sulawesi Selatan. Media Akuakultur. Vol. 2 (2):4

Hernanto, F. 1989. Ilmu Usahatani. Penebar Swadaya. Jakarta

Husnan, S. dan Suwarsono. 1994. Studi Kelayakan Proyek. UPP AMP YKPN. Yogyakarta.

Mubyarto. 1989. Pengantar Ekonomi Pertanian. Lembaga Penelitian Pendidikan dan Penerangan Ekonomi dan Sosial. Jakarta.

Neliyana, B. Wiryawan, E.S. Wiyono, dan T.W. Nurani. 2014. Analisis Kelayakan Usaha Perikanan Pukat Cincin di Pelabuhan Perikanan Pantai (PPP) Lampulo Banda Aceh Propinsi Aceh. Marine Fisheries. Vol. 5(2): 163-169.

Padangaran, A.M. 2010. Analisis Kwantitatif Pembiayaan Perusahaan Pertanian. IPB Press Bogor.

Partadiredja, A. 1985. Perhitungan Pendapatan Nasional. LP3ES. Jakarta.

Pratama, F.A. H. Boesono, dan T. Dwi. 2012. Analisis Kelayakan Finansial Usaha Penangkapan Ikan Menggunakan Panah dan Bubu Dasar di Periran Karimunjawa. Journal of Fisheries Resources Utilization Management and Technology. Vol. 1 (1): 22-31.

Primyastanto, M. dan Istikharoh. 2003. Aplikasi Evaluasi Proyek dalam Aspek Studi Kelayakan (Usaha Pembesaran Ikan Gurami). Fakultas Perikanan. Universitas Brawijaya. Malang.

Rahardi. Regina Kristiawati dan Nazaruddin. 1997. Agribisnis Perikanan. Penebar Swadaya. Jakarta.

Riyanto, B. 1983. Dasar-Dasar Pembelanjaan Perusahaan. Gadjahmada Press. Yogyakarta.

Soeharjo, A. dan Dahlan Patong. 1984. Sendi-Sendi Pokok Ilmu Usaha Tani. Fakultas Pertanian Universitas Hasanuddin. Ujung Pandang.

Soekartawi. 1989. Prinsip Dasar Ekonomi Pertanian. Rajawali Press. Jakarta. 